\title{
O Leviatã hobbesiano e o medo de poderes invisíveis: reflexões filosóficas durante a Pandemia
}

\author{
Hobbesian Leviathan and fear of invisible powers: \\ philosophical reflections during the Pandemic
}

\section{Luiz Carlos Santos da Silva ${ }^{1}$}

1 Graduado, mestre e doutor em filosofia pelo IFCH/Unicamp. Professor adjunto de Filosofia Política Clássica no IFILO/UFU E-mail: luiscavh@yahoo.com.br Orcid: http://orcid.org/0000-0001-8865-8197

RESUMO: O presente ensaio tem por finalidade abordar filosoficamente o cenário de medo e desconfiança instaurado no Brasil e no mundo durante a recente pandemia da COVID-19, a partir de algumas considerações sobre os fundamentos políticos da moderna filosofia de Thomas Hobbes. A questão central tratada pelo trabalho é a influência do medo sobre as ações humanas e políticas dentro de uma situação de desarmonia social avessa aos princípios democráticos. Em primeiro lugar, buscaremos mostrar como o medo é considerado pela filosofia hobbesiana como sendo um sentimento religioso capaz de regular as ações e o entendimento dos indivíduos tanto fora quanto dentro do Estado civil. Em segundo lugar, buscamos mostrar como a maximização do medo social pode resultar em uma desconfiança generalizada entre as pessoas e entre os poderes políticos que apenas promove as crenças e superstições dos discursos religiosos e ideológicos mais radicais. Partindo das considerações de Hobbes sobre os fundamentos da soberania civil, investigaremos algumas relações fundamentais entre o medo, a política e a religião nas bases da moderna política estatal. Podemos dizer que, em linhas gerais, este ensaio busca mostrar como um desentendimento do Estados civil consigo mesmo e com seus poderes constitutivos instaurou na população brasileira, desnorteada politicamente pela crise causada pela pandemia do novo coronavírus, uma condição de medo e desconfiança semelhante ao estado de natureza bélico, descrito por Hobbes no Leviatã.

Palavras-chave: Leviatã, Medo, Pandemia.

ABSTRACT: This philosophical essay aims to discuss the scenario of fear and mistrust established in Brazil and in the world during the recent COVID-19 pandemic, based on some considerations on the political foundations of Thomas Hobbes' modern philosophy. The central issue addressed by the work is the influence of fear on human and political actions within a situation of social disharmony that is averse to democratic principles. First, we will try to show how fear is considered by Hobbesian philosophy to be a religious feeling capable of regulating the actions and understanding of individuals both outside and within the civil state. Second, we seek to show how the maximization of social fear can result in a widespread distrust among people and among political powers that only promotes the most radical religious and ideological beliefs and superstitions. Starting from Hobbes' considerations on the foundations of civil sovereignty, we will investigate some fundamental relations between fear, politics and religion on the basis of modern state politics. Finally, this essay seeks to show how a misunderstanding of the civil states with themselves and with their constitutive powers instilled in the Brazilian population, politically perplexed by the crisis caused by the pandemic of the new coronavirus, a condition of fear and distrust similar to the state of warlike nature, described by Hobbes in Leviathan.

Keywords: Leviathan, Fear, Pandemic. 
"Cantaremos o medo dos ditadores, o medo dos democratas, cantaremos o medo da morte e o medo de depois da morte".

Carlos Drummond de Andrade

\section{O medo como efeito do desconhecimento das causas}

A recente pandemia causada pelo "novo" coronavírus (COVID-19) fez com que parássemos, perplexos, para observar o quanto o medo generalizado de um inimigo invisível a olhos nus pode causar, subitamente, efeitos sociais, econômicos e políticos catastróficos para a história da vida humana em sociedade. E se não bastasse o desconforto contínuo causado por um agente viral invisível, alguns dos principais Estados mundiais, a exemplo da França e da Alemanha, chegaram mesmo a profetizar os futuros efeitos sociais dessa recente pandemia como sendo semelhantes aos horrores sofridos pelos Estados nacionais durante e após a segunda guerra mundial. Nesse registro da guerra generalizada, o conflito entre as partes, a favor e contra o isolamento social, parece ter despertado também uma disputa pela soberania dos Estados. No Brasil, por exemplo, o governo federal desde o início da pandemia se posicionou contrário às orientações da organização mundial da saúde, seguindo na contramão tanto das principais nações mundiais quanto dos próprios Estados e municípios brasileiros. O presidente brasileiro, Jair Bolsonaro, acusou a mídia jornalística e a oposição política de tramarem uma conspiração contra seu governo. O resultado final disso tudo é um medo generalizado que promove a desconfiança das pessoas tanto umas em relação às outras quanto do povo em relação aos poderes políticos do Estado de direito. Diante dessa situação inusitada, convém atentarmos para o fato de que o medo e a desconfiança são duas potentes paixões ancestrais, capazes de regular as ações e as opiniões da população não somente nos âmbitos político e econômico, mas também no religioso.

No caso do Brasil, temos, de um lado, o isolamento coletivo imposto pelos Estados e municípios e, de outro lado, o governo federal acusando, na figura do presidente da república, a mídia e a oposição de conspiração e calúnia. De fato, as medidas sanitárias tomadas contra essa pandemia parecem ter servido também de "matéria de capa" para as mídias sensacionalistas, que historicamente procuram ditar secretamente as cartas nos jogos de interesses políticos e econômicos. O oportunismo midiático parece mesmo resultar na maximização de um medo paralisante da população, que, mais amedrontada do que bem informada, tende a buscar explicações sobrenaturais para aquilo que não pode ver e entender ao certo. Mas, se já não bastasse o medo causado por um agente viral mortífero e desconhecido, o governo federal brasileiro, com o intuito de provocar a população contra as medidas sanitárias de isolamento, justifica suas preocupações econômicas levantando hipóteses de conspirações secretas das oposições políticas. Com isso, instaurase sobre a população um império do medo natural de um inimigo viral invisível e letal, somado ao medo social de um desarranjo institucional do Estado consigo mesmo e com seus poderes constitutivos: executivo, legislativo e judiciário. A soma de todos esses medos parece resultar em prejuízos políticos e econômicos não apenas para os cidadãos e o governo atual, mas também para a política democrática como um todo: federação, estados e municípios.

Convém atentarmos para o fato de que a soma de todos os medos pode vir a instaurar um "novo" modelo de reta ordem social, ministrado de maneira impositiva, mas com o consentimento imediato de uma parcela hegemônica da população dividida. O resultado disso não pode ser outra coisa senão o dissentimento congênito entre os poderes do Estado e os direitos de seus cidadãos. Pois, em situações de exceção como essa causada pela recente pandemia da COVID-19, tanto os Estados e municípios estão autorizados a tomar 
medidas “autônomas” em relação à federação quanto os cidadãos estão igualmente autorizados, por natureza, a se conservarem a todo custo, inclusive desobedecendo leis civis deste ou daquele lado do governo em desarranjo. Acontece que o medo de poderes e de inimigos invisíveis é a matéria que, por coincidência ou não, constitui o modelo soberano e absolutista das autoridades governamentais desde a antiguidade ou antes mesmo da constituição dos Estados civis modernos ${ }^{1}$.

$\mathrm{Na}$ ausência de um Estado civil em harmonia consigo mesmo e com seus poderes, o que impera sobre as relações sociais em situações de calamidade é o medo das pessoas umas em relação às outras, bem como a revolta da população contra os poderes de um Estado civil desorientado. O despreparo do Estado brasileiro para lidar tanto com a pandemia quanto com o esclarecimento da opinião pública sobre precauções sanitárias adequadas parece conduzir nossa atual política estatal rumo a uma patologia congênita que, mesmo depois de se ter diagnosticado e contido o vírus causador dessa pandemia e também recuperado os índices da economia global, pode resultar em sequelas irreversíveis para sobrevivência das velhas repúblicas democráticas novo milênio adentro. Os primeiros sintomas políticos disso parecem ser, no caso do Brasil, o desentendimento patológico do Estado civil tanto consigo mesmo (executivo, legislativo e judiciário) quanto com os cidadãos e os poderes que o compõe nos âmbitos federal, estadual e municipal.

Ao vivenciar a solidão hostil das ruas ao redor de minha residência, durante o isolamento coletivo decretado à universidade federal onde leciono e à cidade de Uberlândia como um todo, não pude deixar de parar em casa para pensar sobre essa situação inusitada pela qual passa a sociedade contemporânea em que vivo. Filosoficamente indagando, será que essa súbita situação de paralisia social, causada pelo medo de um inimigo invisível letal, é mesmo algo tão novo e inusitado a ponto de ter pegado os Estados civis mundiais tão desprevenidos politicamente? Acredito que não. Medidas preventivas importantes poderiam ter sido tomadas de antemão, caso houvesse mais disposição política e econômica dos governos mundiais para com a população e para com o Estado democrático de direito em si. De um lado, os estudos políticos, sociais e ambientais há tempos seguem denunciando a incompetência dos Estados capitalistas para lidar com a conservação dos direitos e do bem-estar social dos povos mundo afora. De outro lado, os estudos científicos mais recentes já vinham anunciando antecipadamente a possibilidade concreta da COVID-19 se propagar em termos de uma pandemia global. Na soma das incompetências, o descaso dos Estados capitalistas em relação tanto à população quanto às ciências parece até mesmo proposital, senão propício às reformas institucionais necessárias para se manter o status quo do secular modelo social vigente rumo ao novo milênio adentro.

Vale lembrar que o medo de inimigos invisíveis fez com que a maior parte das pessoas no medievo acreditasse, por séculos e séculos a fio, na evidência dos discursos religiosos sobre a ação de espíritos demoníacos e divinos. Esses discursos religiosos conduziram as práticas políticas e cientificas durante quase toda a idade média na Europa. Espiritualidades à parte, a história da filosofia política nos mostra que a crença desmedida na ação onipresente de poderes invisíveis fez do medo, da desconfiança, da perseguição e da guerra os pilares da política europeia medieval e de suas inquisições autoritárias. Nesse registro arcaico da história da política e das guerras, vale notar como o medo é um sentimento religioso antidemocrático e que apenas fomenta os autoritarismos mais radicais.

Acontece que a desconfiança gerada pelo medo comum de inimigos invisíveis pode servir também

\footnotetext{
${ }^{1}$ Ao considerar o medo reciproco das pessoas como fundamento tanto da guerra quanto da paz, Hobbes afirma, no primeiro livro do De Cive: "Devemos portanto concluir que a origem de todas as grandes e duradouras sociedades não provém da boa vontade recíproca que os homens tivessem uns para com os outros, mas do medo recíproco que uns tinham dos outros." (HOBBES, 2002, p. 28)
} 
de álibi para as guinadas econômicas e políticas, previstas tanto para o presente quanto para o futuro. O remédio ministrado pelos poderes políticos e econômicos mundiais pode vir a causar efeitos colaterais com sequelas irreversíveis para o futuro da política: a desconfiança dos cidadãos uns em relação aos outros por medo dos poderes de inimigos invisíveis e capazes de fazer de certos "grupos de risco" avatares da má fortuna social. A precaução imposta horizontalmente sobre os cidadãos por um Estado civil em conflito consigo mesmo, sob o domínio do medo, pode acabar fazendo da exceção presente uma regra das relações sociais no futuro.

Apesar da novidade dessa pandemia viral instaurar uma situação política inusitada no Brasil e no mundo, o medo comum de inimigos invisíveis é uma paixão muito antiga. Paixão essa que, quando maximizada socialmente, resulta em uma espécie de "paranoia coletiva" que fomenta as pessoas a evitarem o convívio social por conta de um receio ou preconceito disfarçado de precaução. Precaução essa que pode resultar em uma desconfiança permanente das pessoas entre si. Nessa condição, a desconfiança pode vir a instaurar também uma suspensão das normas de conduta entre os cidadãos, por conta de uma maximização das maiores e mais potentes paixões humanas: o medo da morte e o seu avesso, a saber, a esperança da vida eterna.

Ao vivenciar uma condição hostil de desconfiança imperando sobre as relações sociais ao meu redor, neste momento de pandemia mundial, não pude deixar de pensar no "estado de natureza", descrito pela política dos modernos filósofos contratualistas, particularmente de Thomas Hobbes. Ao ver surgir, diante dos meus olhos, um modo através do qual se é possível instaurar, praticamente do dia para a noite, um "estado de exceção" fundado no medo de poderes invisíveis, não pude deixar de meditar sobre a relação entre o medo, a política e a religião nas bases do Estado civil soberano, sistematizado por Hobbes na figura do seu monstruoso Leviatã.

Hobbes define as ciências naturais e políticas como sendo o conhecimento das causas que produzem os efeitos ou fenômenos investigados pelo entendimento humano. O desconhecimento das causas ou a falta de ciência coincidiria com a matéria sobre a qual Hobbes diz estar edificadas as bases da política estatal: o medo da morte ${ }^{2}$. Esse medo é um sentimento religioso, uma vez que se funda na crença sobre a suposta verdade daquilo que extrapola os campos do entendimento e da experiência humana. O medo é entendido por Hobbes como uma paixão tão potente e irresistível que ela é capaz de regular as ações humanas não apenas na ausência, mas também na presença do Estado civil. Porque a filosofia hobbesiana se assenta sobre princípios do heliocentrismo moderno de Copérnico e Galileu (que entendiam o cosmo e a natureza nos termos de uma autoconservação do movimento), as ações políticas são vistas por Hobbes como movimentos humanos ou sociais que buscam em tudo a autoconservação dos indivíduos. Entendendo a vida como simples movimento (circulação sanguínea e outros movimentos vitais), a finalidade das ações humanas fora e dentro do Estado passam a ser consideradas sob o prisma da autoconservação do movimento dos indivíduos, que rejeitam a morte a todo custo. Daí que, segundo Hobbes, a autoconservação dos indivíduos é o princípio regulador de todas as ações políticas e o medo da morte a maior de todas as paixões que orientam essas ações ${ }^{3}$.

Uma vez que a moderna lei cósmica da natureza e do movimento seria o princípio regulador de todas as coisas existentes no mundo, os homens hobbesianos estariam autorizados, por natureza, a fazerem tudo o que julgassem necessário para a autoconservação de seus movimentos vitais, isto é, da vida. Na busca

2 Ver: Leviatã, I, 14.

3 Sobre esse assunto, consultar meus artigos: "A geometria das paixões humanas na filosofia do poder em Hobbes" e "O Príncipe e o Leviatã: ciência, política e modernidade no contratualismo mecanicista de Thomas Hobbes". 
comum por essa autoconservação individual é que o estado de natureza em Hobbes se caracteriza como uma condição de guerra generalizada de todos contra todos ${ }^{4}$. No registro de uma condição hostil de guerra generalizada, o inimigo oculto, que pode tanto atentar contra a vida dos indivíduos quanto contra a conservação de um Estado desprevenido, desperta na população um duplo medo: o medo tanto das ações dos inimigos invisíveis quanto das reações de um Estado civil despreparado. O problema maior é que, no caso de uma guerra contra inimigos invisíveis, nada mais prudente e sagaz do que se prevenir na antecipação da guerra e se adiantar na peleja, subjugando o maior número possível de potenciais inimigos ocultos.

É nesse registro da desconfiança, gerada pelo medo de poderes invisíveis, que a condição hostil, instaurada nas ruas da minha cidade e Brasil afora, pode ser comparada ao "estado de natureza" descrito pela filosofia política hobbesiana. Pois, o estado de natureza em Hobbes resulta naquela condição em que as pessoas se encontram desamparadas pela segurança das leis civis e, ao mesmo tempo, se sentem ameaçadas por um inimigo invisível que capaz de agir através de qualquer um. Hobbes entende que o medo é compatível com a liberdade das ações humanas tanto fora quanto dentro do Estado, de modo que uma ação tomada em situação de medo deve ser considerada uma ação voluntária e deliberada ${ }^{5}$. O estado de natureza resulta em uma condição de guerra por conta da desconfiança que regula a vontade dos cidadãos, impotentes frente aos poderes de inimigos invisíveis tanto naturais quanto políticos. Os inimigos ocultos, por serem invisíveis e imprevisíveis, acabam por prescrever a desconfiança e a antecipação como medidas preventivas das ações sociais. Por conta dessa desconfiança e medo, o estado de natureza hobbesiano se torna uma condição de guerra e de hostilidade permanente entre os indivíduos não apenas fora, mas também dentro do Estado civil, caso ele não seja de fato soberano.

A exemplo do que acontece nas "guerras frias", nas quais o confronto corpo-a-corpo não acontece muito para além das constantes ameaças e espionagens, a desconfiança e o medo do imprevisível são as paixões que dominam as ações e as reações de todos os lados envolvidos no conflito. A batalha se torna, por assim dizer, uma "guerra psicológica", na qual o inimigo maior resulta da soma dos medos que pode levar à antecipação generalizada deste ou daquele lado. Reação essa cujas potencias bélicas somadas em uma disputa poderiam exterminar a própria raça humana. O fato é que o estado de natureza bélico em Hobbes não consiste necessariamente no confronto da batalha, mas sim naquela condição em que a desconfiança de uns contra os outros impera no comportamento das pessoas e mesmo entre os poderes do Estado. Em uma situação de desconfiança geral na política, o Estado civil entra em confronto com seus próprios poderes constitutivos e os cidadãos podem vir a se considerar potenciais inimigos uns dos outros. O resultado desse desarranjo, sob o prisma hobbesiano, não pode ser benéfico para nenhuma das partes envolvidas no conflito, que inevitavelmente se generaliza como uma espécie de câncer social.

Em uma condição de desconfiança generalizada, diz Hobbes, nada mais conforme ao princípio de autoconservação individual do que a subjugação preventiva de possíveis inimigos futuros: o ataque se torna a melhor defesa. Em situações como essa, certas medidas de prevenção podem vir a se tornar estratégias de antecipação futura, tendo em vista a redução de riscos e danos nas negociações políticas, econômicas e mesmo pessoais. Pois a guerra não consiste necessariamente no ato da peleja, mas sim naquele lapso de tempo em que não há diálogo pacifico entre as partes envolvidas no conflito. E isso parece valer tanto no que diz respeito às relações pessoais dos cidadãos entre si quanto às relações políticas do Estado com seus

\footnotetext{
4 Ver: Leviatã, I, 13.

5 "O medo e a liberdade são compatíveis: como quando alguém atira seus bens ao mar com medo de fazer afundar seu barco (...). E de maneira geral todos os atos praticados pelos homens no Estado, por medo da lei, são ações que seus autores têm a liberdade de não praticar." (HOBBES, 1983, p. 128).
} 
poderes. Para ilustrar esse estado de natureza bélico descrito por Hobbes sob o prisma da desconfiança, cito o capítulo 13 do Leviatã:

E contra esta desconfiança de uns em relação aos outros, nenhuma maneira de se garantir é tão razoável como a antecipação; isto é, pela força ou pela astúcia, subjugar as pessoas de todos os homens que puder, durante o tempo necessário para chegar ao momento em que não veja qualquer outro poder suficientemente grande para ameaçá-lo. E isto não é mais do que sua própria conservação exige, conforme é geralmente admitido;(...). Pois a guerra não consiste apenas na batalha, ou no ato de lutar, mas naquele lapso de tempo durante o qual a vontade de travar batalha é suficientemente conhecida. Portanto a noção de tempo deve ser levada em conta quanto à natureza da guerra, do mesmo modo que quanto à natureza do clima. Porque tal como a natureza do mau tempo não consiste em dois ou três chuviscos, mas numa tendência para chover que dura vários dias seguidos, assim também a natureza da guerra não consiste na luta real, mas na conhecida disposição para tal, durante todo o tempo em que não há garantia do contrário. (HOBBES, 1983, p. 75).

O estado de natureza em Hobbes resulta da antecipação generalizada, oriunda do medo de poderes invisíveis que atentam contra a vida humana fora ou dentro da esfera pública. Trata-se de uma disposição geral das pessoas e dos poderes políticos para a subjugação de um inimigo comum imprevisível. Inimigo esse que, por ser invisível e oculto, pode estar em qualquer lugar e, a qualquer momento, ameaçar a vida tanto dos cidadãos quanto do próprio Estado. Essa desconfiança geral pode ser criada tanto por um agente viral mortífero quanto pela hipótese de uma conspiração de Estado, na qual agentes ocultos podem vir a tramar contra o governo e a população. E assim como as grandes tempestades e inundações mais severas não resultam de algumas poucas pancadas de chuva, mas sim de um período de chuvas que se estende por vários dias ou meses (para não mencionar os dilúvios), a condição de hostilidade que leva as pessoas e os poderes do Estado a uma situação de guerra civil resulta na desconfiança que faz com que as partes se vejam como potenciais inimigas umas das outras: avatares permanentes de inimigos invisíveis e ocultos.

Mas, como uma antecipação generalizada, levantada em nome da autoconservação individual, resultaria em uma condição de guerra e hostilidade contrária à autoconservação de quem quer que seja, o Estado civil soberano e suas leis severas aparecem majestosamente como uma solução inescapável para o problema do desentendimento entre as partes conflituosas do corpo político. Somente um Estado de fato soberano possuiria estrutura constitucional capaz de impor medidas severas de contenção das liberdades sociais e econômicas de modo vertical, decretando uma obediência absoluta em nome do risco de vida e de morte dos cidadãos e do próprio Estado ${ }^{6}$. Medidas de contenção impostas em momentos de emergência e calamidade parecem ser estratégias bastante eficazes na restauração dos Estados soberanos e totalitários, bem como de governos ideológicos e eclesiásticos ${ }^{7}$. Acontece que, para a filosofia hobbesiana, o mesmo medo da morte, que instaura o estado de natureza como uma condição de guerra generalizada, também fundamenta os pilares da soberania absoluta. E uma vez constituída a soberania do Estado civil de um modo tal que todos se encontrem igualmente subjugados ao seu poder soberano contra poderes invisíveis e visíveis, o medo da

\footnotetext{
6 Ao designar a soberania como alma do Estado civil moderno, Hobbes atribui ao soberano um "direito" característico do antigo Estado romano: vitae necisque potestas, isto é, "um direito de vida e de morte". Esse "direito" atribui ao Estado civil o poder de decidir sobre a vida e a morte dos seus cidadãos. Quem tem um poder sobre a vida e a morte de alguém tem sobre 3esse alguém um poder absoluto análogo ao poder divino. É nesse sentido que o direito constitutivo do Estado civil é entendido por Hobbes como um princípio teológico-político: o Leviatã estatal como sendo uma espécie de "Deus mortal".

${ }^{7}$ Hannah Arendt, na obra Origens do totalitarismo (2013, p. 405), observa: "O isolamento pode ser o começo do terror; certamente é o seu solo mais fértil e sempre decorre dele. Esse isolamento é, por assim dizer, pré-totalitário; sua característica é a impotência...".
} 
morte parece continuar sendo o princípio regulador das ações humanas tanto dentro quanto fora desse Estado $^{8}$.

Se a função para qual o Estado civil foi constituído é, segundo Hobbes, garantir a segurança através da ordem e da obediência às leis ${ }^{9}$, o medo da morte e dos poderes invisíveis parece ser mesmo mais eficaz para a manutenção desse Estado do que a promoção preventiva da boa saúde pública do corpo político. Toda vez que impera o medo e a desconfiança, a guerra e o conflito parecem regular, ainda que de modo psicológico ou virtual, as ações e o comportamento dos indivíduos. E é exatamente sobre essa condição hostil de guerra que surge a necessidade da soberania civil em Hobbes. Pois, somente um Estado civil soberano (de preferência monarquista e absolutista) poderia impor aos indivíduos medidas emergenciais capazes de estabelecer, subitamente, uma reta ordem social que se aplique a todo o corpo político indiscriminadamente. E assim como os cidadãos estão autorizados a extrair um dente ou amputar um membro em nome da autoconservação do indivíduo, o Estado civil estaria analogamente autorizado a amputar um membro ou parte do corpo político tendo em vista sua autoconservação.

No caso de uma união de Estados ou de uma República federativa, as decisões políticas se tornam soberanas quando são consensuais e harmônicas entre os poderes constitutivos do corpo político, do contrário cada poder se vê autorizado a seguir, independentemente, a busca de sua própria autoconservação. Quando o Estado entra em colapso e perde o controle orgânico dos seus membros inferiores (cidadãos) e poderes constitutivos (executivo, legislativo e judiciário), o resultado disso conduz a uma confusão paralisante do corpo político como um todo. Nesse caso, a quem se deve obedecer: ao governo federal, estadual ou municipal? Que poder está com a razão: o executivo, o legislativo ou o judiciário? Essa confusão promovida parece resultar tanto da ignorância das causas constitutivas do poder civil quanto de informações distorcidas e hipóteses conspiratórias dos poderes, que apenas fomentam o medo e a insegurança da população. E mesmo se não houvesse razão suficiente para uma tal condição natural de desconfiança generalizada entre os poderes políticos e entre os indivíduos, adverte Hobbes, pessoas ambiciosas e interesseiras costumam fomentar a criação de novos inimigos (invisíveis ou não), com o intuito de restaurar a hostilidade social que faz necessária a "reconstrução" da soberania absoluta do Estado intervencionista, mediante algum "governo provisório" do qual elas possam oportunamente fazer parte e inserir suas próprias demandas hereditárias.

Nos termos da política hobbesiana, o medo seria o melhor conselheiro das ações humanas na busca pela felicidade de uma vida tranquila e duradoura, adquirida também mediante a aplicação de leis civis severas. Acontece que, embora a esperança e os deleites de uma vida social plena e saudável possam levar os cidadãos à "ordem e ao progresso", o medo da morte e dos inimigos invisíveis parece fazer isso de maneira ainda mais contundente e eficaz. As paixões mais potentes são aquelas que determinam a vontade por trás das ações humanas e nenhuma outra paixão humana parece ser mais potente do que o medo da morte; sobretudo daquela morte causada pela ação imprevisível de algum inimigo invisível ou oculto. Para exemplificar essas considerações gerais, cito Hobbes, no capítulo 11 do Leviatã

O desejo de conforto e deleite sensual predispõe os homens para a obediência ao poder comum, pois com tais desejos se abandona a proteção que poderia esperar-se do esforço e trabalho próprios. O medo da morte e dos ferimentos produz a mesma tendência, e pela mesma razão. Pelo contrário, os homens necessitados e esforçados, que não estão contentes com sua presente condição, assim como todos os

\footnotetext{
8 Segundo Giorgio Agamben, ao considerar O flerte do ocidente com o totalitarismo (2016), observa: "No modelo do inglês Thomas Hobbes, (...) o Estado é permanentemente fundamentado no medo e deve, a todo o custo, manter-se assim, uma vez que desse medo ele deriva a sua função essencial e legitimidade.".

9 “Salus Populi (a segurança do povo) é seu objetivo" (HOBBES, 1983, p. 5).
} 
homens que ambicionam a autoridade militar, têm tendência para provocar situações belicosas e para causar perturbações e revoltas, pois só na guerra há honra militar, e a única esperança de remediar um mau jogo é dar as cartas uma vez mais. (HOBBES, 1983, p. 61).

Uma vez que a reta ordem social pode ser alcançada tanto pela esperança da vida quanto pelo medo da morte, pessoas ambiciosas, à margem da vida política concreta, podem muito bem mobilizar abusivamente essas paixões com o intuito de fomentar reformas constitucionais do Estado civil. Isso tudo tendo em vista a inclusão de "novas" demandas políticas, implantadas na agenda estatal através de governos provisórios e emergenciais de manutenção do status quo hereditário: a exceção como regra continuamente atualizada do jogo político colonial. Hobbes adverte como esse tipo de estratégia parece ter sido largamente utilizada por muitos homens ambiciosos que, considerados de grande valor e honra em tempos de guerra e crise, são comumente afastados do poder civil e das decisões políticas em tempo de paz e prosperidade. Ansiosos por ter o poder irresistível do Estado civil nas mãos, muitos homens ou grupos de homens ambiciosos buscam promover a turbulência social, com o intuito de inserir seus próprios anseios em um projeto de reconstrução estrutural do corpo político.

No registro de uma restauração do Estado, alguns políticos ambiciosos podem mesmo fomentar uma condição permanente de desconfiança civil análoga às temporadas de grandes inundações e calamidades, anunciadas tanto pelas previsões climáticas dos noticiários televisivos quanto pelas profecias apocalíticas mais radicais. O Estado civil soberano surge e se mantém exatamente nesses momentos de crise e de confusão, de modo que, na ausência de uma crise que justifique de fato a manutenção intervencionista desse Estado, indivíduos ambiciosos acabam por criar, oportunamente, uma crise ou inimigo invisível que legitime a reconstrução da soberania estatal pelas mãos de "novas" autoridades, em modelos de contínuos governos provisórios, constantemente atualizados e reformados nos ciclos da máquina estatal.

A questão é que esse medo, fomentado contra os poderes de inimigos invisíveis, por mais sensato e razoável que possa ser em casos como o de uma pandemia viral ou de uma conspiração política, é apontado por Hobbes como sendo a raiz da própria religião. Para a filosofia hobbesiana, o desconhecimento das causas ou a falta de esclarecimento das pessoas sobre a produção de certos efeitos é a origem de todos os medos e superstições que fundam o sentimento religioso. Hobbes defende que o entendimento humano do mundo resulta do conhecimento das causas; posto que todo fenômeno manifesto no mundo natural e político deve ser sempre considerado como efeito de alguma causa anterior. Quando a investigação das causas de certos efeitos extrapola o campo da experiência possível ou do próprio entendimento humano, então as pessoas comumente atribuem as origens dessas e daquelas coisas misteriosas a poderes e causas invisíveis. Se os efeitos de causas desconhecidas são agradáveis ou benéficos, então costumam chamar esse poder invisível de divino. Mas, se os efeitos são desagradáveis ou prejudiciais, então costumam chamar o poder invisível que causa esses efeitos de demoníaco. O fato é que, para Hobbes, o medo da morte e o desconhecimento das causas de certos efeitos ocultos constituem as verdadeiras bases do sentimento religioso ${ }^{10}$. Sobre esse assunto, trataremos a seguir.

\footnotetext{
10 No capítulo IV do Leviatã (1983, p.35) Hobbes afirma que "o medo dos poderes invisíveis, inventados pelo espírito ou imaginados a partir de relatos publicamente permitidos, chame-se religião; quando esses não são permitidos, chama-se superstição".
} 


\section{A crença e os discursos sobre poderes invisíveis}

Hobbes identifica as origens das doutrinas religiosas ao ímpeto das pessoas que dizem conhecer as causas e os efeitos daquelas coisas que caem fora do campo da experiência possível e do entendimento humano comum. E é exatamente nesse campo que a filosofia hobbesiana identifica também as origens da autoridade. Pois, para Hobbes, toda autoridade reside no poder das palavras e das ações de uma pessoa representativa que se destaca das outras por conta de um poder atribuído a ela pelas outras pessoas e não pela natureza ou pela divindade celestial ${ }^{11}$. Para a filosofia hobbesiana, nenhuma autoridade civil, cientifica ou religiosa é predicada a alguém por natureza ou pela divindade, mas pelo costume que move a esperança dos outros que depositam sua crença em alguém ou naquilo que esse alguém representa. A causa do medo resultaria do desconhecido e a paixão contrária a esse medo seria justamente a esperança. Esperança essa que, para a filosofia hobbesiana, é o avesso do medo e consiste na espera resultante de uma projeção para o futuro do bem ou do mal que poderiam se realizar no presente ${ }^{12}$.

Nesse sentido, o medo e a esperança parecem ser considerados os dois gumes afiados de uma mesma navalha. Pois, o medo causado no presente por algum agente oculto e imprevisível se projeta como a esperança de se superar, no futuro, os obstáculos presentemente colocados por esse inimigo desconhecido. A esperança, segundo Hobbes, seria uma espécie de positivação do medo presente, que se projeta para o futuro baseado em alguma crença passada. A desconfiança social, implícita na falta de esclarecimento tanto dos governantes quanto dos cidadãos em relação às verdadeiras causas de certos fenômenos invisíveis, tende naturalmente a se projetar do presente rumo ao futuro como crença e superstição, quando não como ideologia. A esperança, entendida como uma projeção invertida do medo, é considerada por Hobbes como sendo a base fundamental da crença que constitui as autoridades representativas tanto do reino dos homens na Terra quanto do reino de Deus nos Céus. A generalização do medo e da desconfiança promove um tipo de "esperança religiosa" que é contraria à saúde tanto dos cidadãos particulares quanto da própria política "laica" ou "ecumênica", que funda as bases dos Estados democráticos de direito ${ }^{13}$.

O medo generalizado de poderes e inimigos invisíveis é uma paixão humana com a qual deve se ter muita cautela. Pois, esse medo, maximizado na população, pode levar o corpo político rumo a um conservadorismo exacerbado, que desperta a intolerância e a discriminação como modos habituais de ações preventivas na política. Tal situação parece ser fomentada por um medo dos poderes invisíveis que leva os cidadãos a atribuírem a boa ou má fortuna da vida social às ações ocultas de deuses e demônios. A falta de um esclarecimento político dos cidadãos comumente leva à crença em intervenções divinas, que fazem dos efeitos positivos ou negativos das decisões políticas recompensas ou castigos de Deus e de seus representantes na Terra. A fé e a crença, segundo a filosofia hobbesiana, começam justamente onde termina o conhecimento, ou seja, configuram o limite cognitivo da experiência humana possível. O medo dos poderes invisíveis, na medida em que encontra suas origens no desconhecimento ou na ignorância das causas, acaba por colocar a fé e a crença no lugar de um conhecimento que deveria fundamentar a base das deliberações políticas dentro de um Estado civil bem constituído.

11 No capítulo 16 do Leviatã $(1983,96)$, Hobbes trata da personificação da autoridade do soberano por representação. Segundo ele, a palavra autoridade deriva de autor e se origina na tradição trágica do teatro. Do teatro, essa palavra teria passado para os tribunais, significando a "autoria" das ações jurídicas propostas pela representação artificial e não pela natureza.

12 "O apetite, ligado à crença de conseguir, chama-se esperança". (HOBBES, 1983, p. 34.).

13 Os fundamentos constitucionais do moderno Estado civil resultam justamente de uma separação entre os poderes espirituais e os temporais, isto é, entre a política e a religião. 
Essa fonte da religião é a mesma que leva as pessoas à crença em autoridades comovedoras daquelas paixões humanas mais radicais: o medo e a esperança. A espiritualidade e a religiosidade, segundo Hobbes, são indissociáveis da vida humana e devem ser consideradas como modos de veneração dos mistérios da natureza, não como conhecimento das causas últimas dos reinos do céu e da Terra. As causas do desconhecido tendem a ser explicadas pelas crenças nos termos dogmáticos de "conhecimentos por revelação", típicos das doutrinas religiosas que buscavam regular o campo das ciências e da política no medievo. A fé desmedida e as crendices exacerbadas pelo discurso inflamados de líderes espirituais radicais ou idealistas ambiciosos fomentam os cidadãos tanto à desobediência civil quanto ao conflito de ideias. Os resultados possíveis de uma tal situação, iniciada por alguns, mas disseminada por todo o corpo social, diz Hobbes, são duas saídas opostas: ou guerra generalizada ou soberania absoluta.

A condição resultante de uma promoção desmedida do medo de inimigos invisíveis acaba por se tornar, de modo análogo ao estado de natureza hobbesiano, um terreno fértil para a discórdia. Terreno esse onde floresce a esperança de homens ambiciosos subirem ao poder e deixarem seu legado hereditário instaurando a guerra e, com ela, a necessidade de um poder intervencionista e reformador, ainda que emergencial e "provisório". Pois, embora o investimento preventivo nas ciências e na educação possa ser, a longo prazo, mais benéfico para o bem público do Estado e de seus cidadãos, muitos governos economicistas ainda insistem na administração do medo como o modo mais eficaz e imediato de se obter a obediência civil e a reta ordem social. De um lado, o medo da morte e, de outro, a esperança na sorte ou em milagres. A soma final disso tudo é uma inércia social análoga a uma paralisia do corpo político inteiro, mas com o espirito soberano das leis pulsante nas mentes e corações dos indivíduos amedrontados.

Diante da excepcionalidade da situação que essa pandemia da COVID-19 despertou no mundo contemporâneo, insisto naquela pergunta inicial: será que os Estados civis mundiais não poderiam ter se precavido de modo mais eficiente contra essa terrível catástrofe? Ao que repondo: certamente poderiam. Pois, a experiência com epidemias anteriores (inclusive de outras versões do mesmo vírus), bem como os alertas antecipados de pesquisadores e da própria organização mundial da saúde, deveriam ter ensinado aos Estados, senão uma vacina eficiente contra a doença, ao menos formas eficazes de prevenir antecipadamente o contágio epidêmico. A razão estratégica de um Estado civil saudável deveria regular, com políticas públicas constitucionais, a prevenção desses casos que colocam em risco não apenas a vida dos cidadãos, mas também a saúde do próprio corpo político como um todo. Se o fomento ao medo generalizado contra inimigos invisíveis não foi algo premeditado por forças políticas estranhas à diversidade cultural do mundo globalizado, ao menos parece estar sendo, ainda que fatidicamente, bastante conveniente para a restauração do protecionismo ideológico e teocrático do medievo rumo ao novo milênio adentro: o império do Medo ${ }^{14}$.

O discurso de muitos Estados civis, que tratam a pandemia nos termos de uma guerra mundial, revela como parece haver interesses políticos e econômicos obscuros por trás da "reviravolta histórica" causada pelo vírus da COVID-19. A China, país onde primeiramente foi constatado o surto do vírus, anuncia a contenção do contágio desenfreado e a redução dos casos mais graves da doença. O "controle" da pandemia, por parte de alguns Estados mais avançados, parece mostrar que medidas sanitárias, médicas e hospitalares adequadas podem ser políticas públicas bastante eficazes no combate à contaminação generalizada do vírus. Desde que haja disposição política e econômica imediata. essa pandemia parece poder ser

\footnotetext{
14 Segundo a mitologia greco-romana, Medo foi um antigo rei tirano, filho de Medéia. Dizem que, ao expandir seu domínio sobre territórios onde hoje se situa a atual Europa, Medo costumava batizar as cidades por ele conquistadas de "médias", em homenagem à sua mãe Medéia. Por conta disso, inclusive, filósofos modernos, a exemplo de Hobbes, retrataram o medievo como a "idade das trevas", em uma alusão direta ao mitológico "império do Medo".
} 
controlada em um período de tempo relativamente curto, caso haja interesse dos Estados em desenvolver tratamentos e vacinas eficazes. Comparar desde o início essa pandemia da COVID-19 às fatalidades do holocausto, aquele período histórico de destruição e barbáries contra a dignidade humana, parece ser, no mínimo, um disparate. Isso porque, a imagem da segunda guerra mundial carrega consigo a memória histórica de um período de crises econômicas e sociais em que predominava os interesses dos Estados soberanos e das políticas totalitárias sobre os direitos e a vida de incontáveis pessoas inocentes.

No Brasil, o governo federal insiste em posicionar-se contrário às recomendações da OMS e ainda instiga os cidadãos a abandonarem o isolamento social coletivo pensamento na economia, mas sem apresentar nenhum plano estratégico de orientações sanitárias ou políticas eficazes. As reações inconsequentes do governo federal frente ao impasse social, econômico e político causado pela pandemia da COVID-19 parece apenas fomentar ainda mais a gravidade da situação. Pois, a incongruência das ações tomadas pelo presidente da república durante essa crise acaba por isolar a população de um lado e segregar os signatários do governo de outro, colocando tanto a população quanto o Estado e seus poderes em confronto direto consigo mesmos, justamente em uma situação em que deveria acontecer um distanciamento social harmônico. As ações de quem se encontra à testa de um governo de Estado devem zelar, em tudo, pela conservação da vida dos cidadãos, tanto quanto pela própria constituição civil. O descuido com esse princípio de autoconservação do Estado e de seus membros, seja lá qual for o regime administrativo do governo, pode abrir fendas estruturais graves nos pilares que sustentam o próprio edifício "laico" ou "ecumênico" do chamado Estado democrático de direito.

Apesar da excepcionalidade da situação causada por essa pandemia, a educação e o esclarecimento da população bem formada e informada deve ser sempre o remédio mais eficaz, não apenas para a erradicação de pandemias como essa, mas também contra futuras calamidades semelhantes. Pois, se essa não é a primeira pandemia de proporções globais, sofrida pelos modernos Estados nacionais depois da segunda grande mundial, certamente não será a última. No melhor dos mundos possíveis, a educação política, acompanhada de todos os recursos necessários para a execução da boa saúde física e mental da população, seria a melhor vacina contra essa e outras calamidades futuras. E isso pensando não apenas na saúde dos cidadãos, mas também na integridade do corpo político do próprio Estado democrático de direito como um todo.

O modo como os Estados ocidentais lidaram com a "surpresa" causada pela rápida proliferação do vírus da COVID-19 parece ter fomentado a instauração de um "estado de sítio mundial", cujas sequelas sociais no futuro podem ser ainda maiores do que aquelas causadas pela própria contaminação do vírus: a desconfiança como regra permanente das ações políticas novo milênio adentro. O desprezo pelos perigos dessa pandemia, oriundo de interesses meramente econômicos de mais um ano eleitoral, parece também despertar nos cidadãos e nos governantes um medo semelhante do desconhecido e do imprevisível. A soma de todos esses medos parece resultar em um desarranjo político entre governo e oposições que instaura uma espécie de paralisia generalizada do corpo político, análoga a uma "síndrome do pânico" na população. Nessa condição de suspensão do controle do Estado sobre seus órgãos e suas funções mais básicas, os discursos ideológicos e as superstições sobre poderes invisíveis e espíritos imateriais ganham força e autoridade tanto política quanto científica.

Ao se fomentar o medo e a desconfiança entre os cidadãos também se desperta uma disposição dos mesmos às crenças e ideologias religiosas mais radicais. Pois, o medo, segundo análise da filosofia hobbesiana, leva as pessoas a acreditarem nos discursos religiosos mais inflamados sobre causas e coisas absurdas. Esses discursos costumam regular, de modo bastante eficaz, as ações sociais para além das decisões políticas e econômicas. Diante da paralisia de um Estado civil em conflito consigo mesmo, a "revelação divina" faria 
de certos "eleitos por Deus" pessoas escolhidas para acessar, de modo profético e oculto, o conhecimento das causas do invisível e do misterioso. Fomentar o medo contra poderes e inimigos invisíveis é negar à população o esclarecimento das causas sobre certos efeitos reais e também abrir margem para o pensamento supersticioso que regula as crenças e ideologias dos Estados antidemocráticos. Para exemplificar, cito Hobbes, no capítulo 29 do Leviatã:

porque o receio da escuridão e dos espíritos é maior do que os outros temores, não pode deixar de congraçar um partido suficiente para a desordem e muitas vezes para a destruição de um Estado. E isto é uma doença (...); assim também, no corpo político, quando o poder espiritual agita os membros de um Estado pelo terror dos castigos e pela esperança das recompensas (que são seus nervos) e não pelo poder civil (que é a alma do Estado) como deviam ser movidos, e por meio de palavras estranhas e difíceis sufoca seu entendimento, precisa por isso de distrair o povo, e ou submergir o Estado na opressão, ou lançá-lo no fogo de uma guerra civil (HOBBES, 1983, p. 196).

Sob o prisma da autoconservação do próprio corpo político, caberia constitucionalmente ao Estado civil bem edificado educar os cidadãos para casos emergenciais como o de uma pandemia viral e não fomentar o medo e a desconfiança contra os poderes de um inimigo invisível deste ou daquele lado. Pois, o pânico e o terror podem ser causados pelo medo de um poder invisível agindo tanto por meio de uma pandemia quanto por meio de uma conspiração política de oposição ao governo. Em situações excepcionais como essa, os cidadãos costumam acreditar mais em explicações espirituais ou religiosas do que nos avanços científicos e nos efeitos de ações políticas deliberadamente racionais. Como no campo da religião, a força dos discursos inflamados funda mais a verdade profética do que a evidência dos fatos (sobretudo se tratando de poderes e inimigos invisíveis). Nesse caso, as disputas entre ideias, pessoas e partidos acabam se tornado a regra da ação política. Por isso, inclusive, a situação conflituosa em que hoje se encontra o Brasil, por medo de inimigos invisíveis de todos os lados, pode ser comparada ao estado de natureza hobbesiano, tal como exemplificado acima. A consequência disso é um desentendimento político que se instaura não apenas entre os cidadãos, mas antes mesmo entre os poderes governamentais que constituem o Estado civil brasileiro hoje.

Ao abrir terreno fértil para o florescimento de discursos ideológicos e religiosos contra a boa ou má fortuna social advinda de inimigos invisíveis, o Estado civil está, por assim dizer, "cavando a própria cova". É claro que isso tudo pode ser também usado como uma estratégia política de "reconstrução" ou reforma do velho Estado civil, fazendo uma alusão à Fênix mitológica, que, depois de morta, renasceria ainda mais forte das cinzas ${ }^{15}$. Contudo, colocar a desconfiança e o medo de inimigos invisíveis como alicerces de uma política emergencial parece ser um péssimo projeto de engenharia social. Pois, o Estado civil acaba por substituir o princípio político da deliberação racional por um fundamento místico ou religioso contrário às suas próprias origens constitucionais. E assim, junto com a Fênix renascida, pode vir a surgir desse renascimento um "novo" governo teocrático, restaurado sobre as cinzas restauradas do antigo Estado romano, portanto avesso à política participativa, democrática ou republicana. Um Estado teocrático ancorado no medo dos cidadãos pode reduzir a cinzas as conquistas históricas da política como um todo, uma vez que, para um pensamento religioso mais apocalíptico, "do pó viemos e ao pó retornaremos".

O fato é que, segundo as observações hobbesianas sobre as origens e a dissolução do Estado civil, essa condição de medo generalizado entre as pessoas resulta em basicamente duas situações: estado de

${ }^{15}$ A Fênix é um pássaro da mitologia grega que, quando morria, entrava em autocombustão e, passado algum tempo, ressurgia das próprias cinzas. 
natureza bélico e constituição civil soberana. No primeiro caso, o medo de poderes invisíveis naturais gera a desconfiança e a antecipação das pessoas que fazem do estado de natureza uma condição de guerra generalizada. No segundo caso, a superação da desconfiança e do medo que dividem a população e os poderes políticos exige medidas legais severas que apenas um Estado soberano e independente é capaz de implementar. O primeiro caso é destruição e o segundo caso é reconstrução. Assim, a maximização do medo de inimigos invisíveis é aquilo que Hobbes aponta como sendo as origens tanto da guerra civil quanto da paz, isto é, tanto do estado de natureza quanto da soberania estatal.

O problema maior ainda parece resultar da combinação desmedida dessas duas condições, imposta pela soma dos medos: o medo dos poderes letais de um inimigo viral invisível e o medo comum das ações ou reações de um Estado civil desgovernado. O resultado final disso parece ser uma espécie de paralisia social patológica e de graves sequelas a curto, médio e longo prazo. Considerando que a soberania civil é também uma espécie de poder invisível (pois, embora possamos ver os efeitos do Estado, na figura de seus representantes, não somos capazes de ver o próprio Estado), os discursos religiosos e ideológicos mais inflamados tendem a regular não somente as ações individuais dos cidadãos, mas também as próprias ações do Estado e de seus poderes. Não sei se de proposito ou se por ignorância das causas mesmo, a postura do governo brasileiro diante dessa pandemia parece fomentar, de todos os lados, um medo generalizado que instaura a hostilidade tanto entre os cidadãos quanto entre os poderes políticos do próprio Estado. Essa condição parece ser propicia ao surgimento de "novos" poderes ideológicos e eclesiásticos, na disputa pela reconstrução de um Estado civil arruinado política e economicamente pela doença e pela guerra intestina do presente e do passado.

Não sou do tipo que gosta de profetizar catástrofes apocalípticas, analisando, no presente, previsões futurísticas no passado remoto. Tento apenas escrever minhas inquietações e estudos, no registro de meu trabalho histórico-filosófico, particularmente neste período de quarentena geral. Mas, diante da excepcionalidade da situação instaurada por essa pandemia da COVID-19, as considerações de Hobbes sobre as origens remotas do Estado civil soberano parece nos alertar sobre possíveis rumos teocráticos que a política estatal pode vir a tomar doravante, novo milênio adentro. Vale lembrar que o Estado civil é descrito por Hobbes como sendo uma espécie de gigantesco "homem artificial", semelhante a um "Deus mortal"16. No registro mecanicista da filosofia hobbesiana, o Estado civil é considerado uma máquina ou "homem artificial" porque é um artefato criado à imagem e semelhança dos próprios homens naturais, seus artífices. Esses homens, artífices do Estado, são também considerados máquinas por serem criaturas confeccionadas pelas mãos de um Deus criador. Assim, embora a constituição do Estado civil moderno envolva ciência e política, para Hobbes, as bases da política estatal se fundam sobre princípios propriamente religiosos.

É por essa razão que Hobbes descreve a figura do seu monstruoso Leviatã estatal como sendo uma gigantesca máquina, metade humana e metade divina: um "Deus mortal", criado pelos homens e para os homens. Quando o corpo social padece de um medo patológico, causado por agentes invisíveis (pandemias virais ou conspirações políticas intestinas), as crenças em superstições capazes de combater os poderes letais de inimigos invisíveis e ocultos é uma disposição quase que natural ou automática dos cidadãos, conduzidos mecanicamente pelo ímpeto da autoconservação de si. O medo generalizado da população pode causar uma "paralisia social" no corpo político inteiro, deixando o Estado civil, por assim dizer, em uma condição de "suspensão dos juízos" semelhante a um estado de coma induzido. Esse "estado de coma político", causado

16 No capítulo 17 do Leviatã (1983, p. 106), Hobbes afirma que “É esta a geração daquele grande Leviatã, ou antes (para falar em termos mais reverentes) daquele Deus Mortal, ao qual devemos, abaixo do Deus Imortal, nossa paz e defesa." 
pelo medo paralisante maximizado, pode conduzir a política a uma inevitável situação de exceção, que suspende o controle político do Estado sobre suas funções orgânicas mais básicas: seus poderes e membros constitutivos.

Em uma situação política de suspensão dos juízos, a soberania civil (que, para Hobbes, consiste na alma do Estado) tende naturalmente a governar o corpo político do Estado paralisado, de modo análogo a como o "espírito" comanda as funções orgânicas mais básicas de alguém em coma ou em "estado vegetativo". Em uma condição análoga a um "coma político", o sistema imunológico de autodefesa do corpo social acaba por assumir as funções mais básicas do Estado civil. E uma vez entendida a soberania civil nos termos relativos à alma ou ao espírito do Estado, os discursos ideológicos e religiosos mais inflamados parecem ser os mais eficientes na condução das ações e das vontades políticas dos cidadãos do que as deliberações políticas. Para exemplificar a dicotomia entre os poderes políticos e os espirituais, cito novamente Hobbes, no capítulo 29 do Leviatã:

Pois apesar da insignificante distinção entre temporal e espiritual, não deixa de haver dois reinos e cada súdito fica sujeito a dois senhores. Pois, dado que o poder espiritual assume o direito de declarar o que é pecado, assume por consequência o direito de declarar o que é lei (nada mais sendo o pecado do que a transgressão da lei) e, dado que por sua vez o poder civil assume o direito de declarar o que é lei, todo súdito tem de obedecer a dois senhores, ambos os quais querem ver suas ordens cumpridas como leis, o que é impossível. Ora, se houver apenas um reino, ou o civil, que é o poder do Estado, tem de estar subordinado ao espiritual, e então não há nenhuma soberania exceto a espiritual; ou o espiritual tem de estar subordinado ao temporal e então não existe outra supremacia senão a temporal. Quando, portanto, estes dois poderes se opõem um ao outro, a Estado só pode estar em grande perigo de guerra civil e de dissolução. (HOBBES, 1983. p. 196).

Hobbes entende a soberania como a alma da política, responsável por atribuir movimento e vontade ao corpo do Estado civil inteiro. O desarranjo entre os poderes constitutivos do Estado é análogo a um desarranjo entre o corpo e seu espírito. Esse desacerto entre as partes constitutivas da política estatal, lembrando as origens teológicas do Estado, pode levar os cidadãos à confusão de servirem a dois ou mais senhores. De um lado, instala-se o poder político do Estado civil em conflito consigo mesmo e, do outro, os poderes ideológicos ou espirituais de líderes particulares ${ }^{17}$. Essa crise patológica do Estado civil consigo mesmo se estende tanto para a relação dos governos com os cidadãos quanto para a relação dos governos municipais e estaduais com a federação. E considerando a história da política, desde o medievo até nossa contemporaneidade, parece ser bastante retrógrado um movimento de manutenção, reforma ou reconstrução do Estado civil que restaure as velhas bases do medo e da desconfiança como os pilares da cultura social futura.

Particularmente falando, ao considerar a matéria do medo e da desconfiança como fundamento da moderna política estatal, meu ímpeto em querer especular futuros efeitos políticos sob o olhar hobbesiano do passado é quase tão involuntário quanto minha quarentena prudencial. A situação hostil pela qual passa nossa atual sociedade globalizada manifesta semelhanças conceituais profundas com o estado de natureza hobbesiano. Divagando sobre possíveis inferências dessa comparação filosófica entre as considerações hobbesianas e a atual pandemia, notei que a palavra latina corona (utilizada para se referir ao vírus da COVID-

\footnotetext{
17 No capítulo XX do Leviatã (1983, p. 123), Hobbes exemplifica: “Quanto à geração, quis Deus que o homem tivesse uma colaboradora, e há sempre dois que são igualmente pais; portanto o domínio sobre o filho deveria pertencer igualmente a ambos, e ele deveria estar igualmente submetido a ambos, o que é impossível, pois ninguém pode obedecer a dois senhores."
} 
19) significa "coroa". Isso me fez lembrar que Hobbes é um grande teórico da monarquia absolutista, representada na figura monárquica da coroa inglesa, politicamente vigente ainda nos dias de hoje. Monarquia essa que Hobbes retratou na figura do seu monstruoso Leviatã. Seguindo a divagação filosófica, lembrei que corona pode também se referir à uma espécie de "aliança", significando tanto um anel dourado quanto uma união, convenção ou partido de aliados. Isso me fez lembrar também que Hobbes é um grande teórico do pacto ou contrato social. Pacto ou contrato social esse defendido por Hobbes nos termos de uma grande aliança ou convenção de pessoas representativas: os artífices do Estado. Por último, descobri que a palavra corona é também um termo latino utilizado cientificamente desde a modernidade para denominar a "coroa do sol", isto é, aquela aureola iluminada que circunda o astro rei durante os eclipses e acobertamentos solares. Isso me fez lembrar que Hobbes também defendeu uma modernidade heliocêntrica contra o obscurantismo medieval das políticas eclesiásticas como uma espécie de esclarecimento racional ${ }^{18}$. Heliocentrismo esse que fez da moderna política de Hobbes uma teoria da máquina do Estado soberano representado pela própria figura do Leviatã.

Nos termos do heliocentrismo moderno que fundamenta a política mecanicista do Leviatã estatal de Hobbes, o mito por trás do Estado civil parece ilustrar, por analogia, o atual "eclipse político" de modo semelhante a um estado de natureza bélico típico do medievo: a chamada idade das trevas e das guerras religiosas. Essa condição hostil, na qual o medo de inimigos invisíveis gera a desconfiança das pessoas e também a emergência de alguma autoridade soberana, é muito fértil para o florescimento das ideologias e religiosidades radicais contrárias à democracia. A ideia de "aliança”, oculta por trás do nome do agente viral dessa pandemia, poderia até mesmo ilustrar o propósito de uma reconstrução ou restauração do velho e antigo pacto social, tratado por Hobbes nos termos da constituição de uma gigantesca autoridade artificial: o Estado soberano. A sombra do Leviatã hobbesiano, meio máquina, meio homem e meio Deus parece ser justamente a imagem que obscurece o sol do esclarecimento frente à essa "nova aliança", forjada na somatória dos medos e posta como base da política estatal do novo milênio.

Particularmente falando, não gosto sequer de imaginar o cenário do possível mundo futuro, ilustrado politicamente a partir de uma somatória desses medos presentes: um poder teocrático monarquista, absolutista, antidemocrático e de tendência hereditária. Esse "poder bizarro", restaurado geneticamente das cinzas do medievo europeu diretamente para o novo milênio, atualizaria os velhos modelos políticos sobre os protestos metafísicos de "novos" líderes políticos/religiosos. Esse tipo de poder teológico-político é análogo àqueles poderes régios do medievo, nos quais o governo era estabelecido hereditariamente por revelação divina e não por deliberação política ou eleitoral. Esse parece ser um cenário político possível no futuro remoto, considerando o resultado dessa soma de medos políticos e espirituais como projeção de uma "nova" reconstrução do velho Estado soberano rumo ao novo milênio.

Mas, querendo muito ser otimista, como de costume, espero que esse cenário catastrófico, cogitado como possível futuro da política estatal milênio adentro, seja apenas divagação filosófica, resultante do pasmo em que me encontro diante dessa pandemia gerada por inimigos invisíveis (naturais e políticos) de todos os lados. Prefiro acreditar que o esclarecimento dos cidadãos e a política deliberativa sejam capazes de transformar, através do ensino, da pesquisa e da cooperação, esse veneno social em algum antidoto político contra os males fortuitos no futuro. Males esses capazes de fazer renascer das cinzas velhas crendices e superstições outrora erradicadas. Dentro do atual processo de restaurações estruturais das velhas repúblicas,

18 Vale lembrar que o título da famosa obra é Hobbes é Leviatã ou matéria, forma e poder de um Estado civil e eclesiástico. O Estado hobbesiano é soberano e independente justamente por ser integral, ou seja, por surgir da fusão entre o corpo e a alma na constituição de um homem artificial. 
o novo milênio se anuncia através de reformas políticas e econômicas que atualizam antigos projetos de construção do reino dos céus na Terra. As consequências disso tudo parecem ser imprevisíveis, mas certamente contrárias à democracia e à diversidade cultural historicamente conquistadas.

Diante das tantas imprevisibilidades, geradas por essa crise pandêmica do "novo" coronavírus, alguns arranjos mais populares merecem nossa reflexão. Pois, embora a prudência nos imponha o afastamento social como o único remédio possível para controlar essa pandemia, convém lembrarmos do que já dizia o poeta Gil: "é preciso estar atento e forte, não temos tempo de temer a morte" 19 . E isso porque, segundo as experiências de Tom Jobim e de Vinicius de Moraes, "o medo pode matar o teu coração" 20 . E apesar de todo o nosso entendimento desafinado nesse momento de desarranjo histórico, justamente quando que mais precisávamos de harmonia entre os cidadãos e entre os poderes do Estado, de uma coisa eu tenho certeza, ao lembrar de um tempo em que as pessoas ainda se reuniam no "Clube da Esquina" perto de casa: "sei que nada será como antes, amanhã..... ${ }^{21}$.

\section{Referências}

ARENDT, H. (1951). Origens do totalitarismo. Trad. Roberto Raposo. São Paulo: Ed. Cia das Letras, 2013.

AGAMBEN, G. (2016). O flerte do ocidente com o totalitarismo. Inverno de 2016. Acessado no dia 08/05/2020 e disponível em: <https://outraspalavras.net/tecnologiaemdisputa/agamben-o-fler te-do-ocidente-com-o-totalitarismo/>.

HOBBES, Th (1642). Do Cidadão. Tradução apresentação e notas de R. J. Ribeiro. (2ª edição). São Paulo: Ed. Martins Fontes, 2002.

(1651). Leviatã. Tradução e notas de J. P. Monteiro e M. B. Nizza da Silva. In: “Os Pensadores", $3^{a}$ edição. São Paulo: Abril Cultural, 1983.

(1656). Do Corpo (parte I: Cálculo ou lógica). Trad. Maria Isabel Limongi. In: "Coleção multilíngue de filosofia”. Campinas: Ed. Unicamp, 2009.

SANTOS DA SILVA, L. C. "O Príncipe e o Leviatã: ciência, política e modernidade no contratualismo mecanicista de Thomas Hobbes”. In: Revista Cemodecon, v. 2, p. 225. Unicamp, Campinas, 2018.

A geometria das paixões humanas na filosofia do poder em Hobbes" In: Revista Trilhas filosóficas, v. 8, n. 1. Ed. UERN, Natal, 2015.

“Elementos políticos de uma moderna filosofia do poder em Hobbes: o utilitarismo das ciências contra a neutralidade da razão prática". In: Evaldo Becker et al. (Org.). Moral, ciência e história no pensamento moderno. v. 1, pp. 107-132. Editora UFS, Sergipe, 2018.

Artigo recebido em: 09 de maio de 2020

Artigo aceito em: 10 de setembro de 2020

19 GIL, G. e VELOSO C. “Divino, Maravilhoso". In: Tropicália (LP). Philiphs Records, Rio de Janeiro, 1969.

20 MORAES, V. e JOBIM, A. C. "Água de beber". In: The composer of desafinado, plays (LP). Verve Records, New York, 1963.

${ }^{21}$ NASCIMENTO, M. e BASTOS, R. “Nada será como antes”. In: Clube da esquina (LP). EMI - Odeon redords, São Paulo, 1972. 